\title{
RESTRAIN HYPERCHOLESTEROLEMIA WITH ORANGE AND MANDARIN VOLATILE AND FOLDED OILS
}

\author{
A. Z. M. Badee ${ }^{\bowtie}$, Shahinaz A. Helmy ${ }^{1}$, Rushdy M. A. ${ }^{2}$ \\ ${ }^{1}$ Food Science Department, Faculty of Agriculture, Cairo University, Giza, Egypt. \\ ${ }^{2}$ Special Food and Nutrition Department, Food Technology Research Institute, Agricultural Research \\ Center, Giza, Egypt. \\ $\bowtie$ drbadee1947@gmail.com \\ https://doi.org/10.34302/crpjfst/2020.12.3.1

\begin{tabular}{|c|c|}
\hline Article history: & \multirow{12}{*}{ 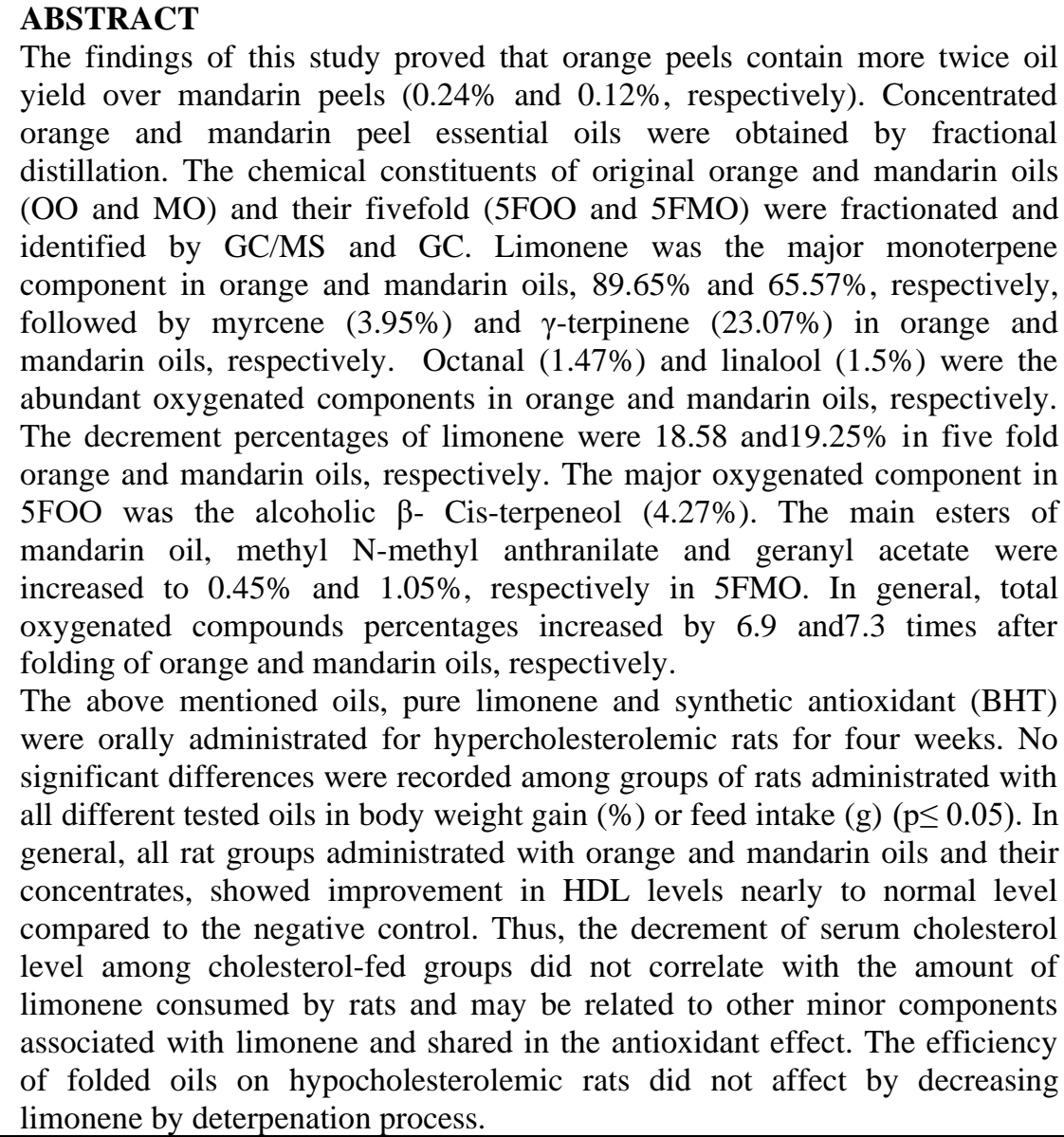 } \\
\hline & \\
\hline 28 April 2020 & \\
\hline Accepted: & \\
\hline 5 August 2020 & \\
\hline Keyv & \\
\hline & \\
\hline & \\
\hline & \\
\hline $\begin{array}{l}\text { Folded olls, } \\
\text { Hypo-cholesterolemic rats, }\end{array}$ & \\
\hline D-limonene. & \\
\hline & \\
\hline
\end{tabular}

\section{Introduction}

Orange (Citrus sinensis) and mandarin (Citrus reticulata) fruits are belonging to Rutaceae Family which follows up genus Citrus (Bourgou, et al., 2012). Citrus peel volatile oils, as by- products of the citrus processing, have wide uses primarily they are used as aroma flavor in many food, pharmaceutical and cosmetic products (Stuart et al., 2001a). Recently, other applications make use of limonene, the major compound of the oil extracted from citrus peels, as a green solvent 
for lipids extraction (Mamidipally and Liu, 2004 and Virot et al., 2008).

Citrus essential oils are a mixture of volatile compounds consist mainly of monoterpene hydrocarbons, which produce high levels of unsaturated and unstable components by oxidation and hydration in the presence of many factors such as light and heat (Ferhat, 2007). The deterpenation process, concentration of citrus essential oils, separates the relatively odorless and flavorless hydrocarbons from the oxygenated components which are more highly odoriferous and flavored. Deterpenation is a relative term and the complete removal of terpene hydrocarbons from citrus oil is not usually achieved or even desired. In practice, any oil which has removed $50 \%$ or more of its terpene hydrocarbons could be described as terpeneless despite the fact that the percentage of remaining hydrocarbons is still high (Tzamtzis et al., 1990). Citrus oils from which terpenes have been removed are called folded oils as the remaining flavorful oxygenated compounds are more concentrated. The degree of concentration is often calculated from the ratio of the principal constituent in the concentrated oil to that in the prime oil from which it was made (Bettini, 2007). Folded orange oils are used as a food ingredient and also as a flavor enhancer in beverages. They can be incorporated into new and existing formulations to enhance fragrance and color.

Hypercholesterolemia and its associated cardiovascular diseases (CVD) represent one of the greatest worldwide economic, social and medical challenges that we are currently facing (Olshansky et al., 2005). Hypercholesterolemia also plays a pivotal role in the development of atherosclerosis, which is a leading cause of death. The relationship between plasma lipid and lipoprotein concentrations and the risk of developing cardiovascular disease (CVD) on the basis of dietary fat type is well documented (Krauss et al., 2001). In addition, the high level of cholesterol in blood have been found to be a major risk factor for the development of atherosclerosis (Brunzell et al., 2008). It is noteworthy that, Ancient Egyptians have used aromatic oils as early as $4500 \mathrm{BC}$ in cosmetics and ointments. They made a mixture of herbal preparations from aniseed, cedar, onion and garlic in medicine (Baser and Buchbauer, 2010). Also, the use of aromatic oils more than 700 substances including ginger, myrrh, sandalwood and cinnamon as being effective for healing, in China and India, for a long time in ancient era (Pauli and Schilche, 2009).

D-limonene, 1-methyl-4-(1-methylethenyl) cyclohexane, is a mono cyclic monoterpene that is mainly present in citrus essential oils with lemon-like odors. Santiago et al. (2010) studied the effect of d-limonene on blood pressure, plasma lipids, circulatory lipid peroxidation byproducts and antioxidant status in young male Wistar rats fed a high fat diet. They ascertained that d-limonene should be considered as a promising lipid lowering agent and antioxidant activities with blood pressurelowering properties.

D-limonene is listed in the Code of Federal Regulations as generally recognized as safe (GRAS) as a flavoring agent in common foods such as fruit juices, soft drinks, baked foods, ice cream and desserts. In humans, D-limonene has demonstrated low toxicity after repeated dosing for up to one year. The studies showed that D-limonene inhibits lipid per-oxidation and prevents free radical-induced damage, physical and psychological stress and stress-induced hypertension. D-limonene has also been reported to have important biological activities, such as antioxidant properties, antiinflammatory activities and chemo-preventive or chemotherapeutic properties against several types of cancer as mentioned by Jing et al. (2013).

Consequently, the present study has been carried out to investigate the deterioration in chemical composition, terpenes and oxygenated components, of original orange and mandarin peel oils after concentration, folding, by GC/MS, as well as evaluate the effect of administrated original and concentrated oils, depending on their limonene content, on 
growth performance, serum lipid profile as well as serum liver and kidney functions of hypercholesterolemic rats.

\section{Materials and Methods}

\subsection{Materials}

\subsubsection{Plant materials}

Mature orange (Citrus sinensis) and mandarin (Citrus reticulata) fruits, balady variety (the local variety in Egypt) were purchased from from El-Shabrawey Farm, Wadi-Elmolak, Sharkia Governorate, Egypt and Al-Amal Farm, Wadi El Natrun, Beheira Governorate, Egypt.

\subsubsection{Authentic Compounds}

Twenty authentic hydrocarbons (GCgrade), including limonene( $\mathrm{C} 8-\mathrm{C} 23$ n-alkanes), as well as Butylated hydroxy toluene (BHT) were obtained from Merck-Schuchardt, Munich, Germany.

\subsubsection{Experimental animals}

Forty eight male Albino rats (Wister strain, in bred, with average weight 140-150 g) were obtained from the Research Institute of Ophthalmology, Giza, Egypt.

\subsection{Methods}

Extraction of orange and mandarin peel oils The oils of both orange and mandarin peels were extracted by applying cold pressing method according to the method of Ahmad and Rehman (2006), the washed peels were shredded to small pieces $(\sim 0.5 \times 0.3 \mathrm{~cm})$, cold pressing was done at ambient temperature by a manual piston. The obtained extract was centrifuged at $4000 \mathrm{rpm}$ for $20 \mathrm{~min}$. at $4^{\circ} \mathrm{C}$. After centrifugation, the separated oil was then treated with anhydrous sodium sulfate. The oil was kept in opaque glass bottles at $-18^{\circ} \mathrm{C}$, until used. Oil yield was calculated as follows: Oil yield $\%(\mathrm{w} / \mathrm{w})=$ (quantity of obtained oil / quantity of used peels $) \times 100$

\subsubsection{Concentration of essential oils (Folding) \\ orange and mandarin essential oils were concentrated by vacuum distillation $(10 \mathrm{~mm}$}

bar, $45-55^{\circ} \mathrm{C}$ for $2.5-3 \mathrm{hr}$.) to obtain fivefold oils according to the method described by Stuart et al. $\left(2001_{b}\right.$ ). The obtained oils were stored at $2^{\circ} \mathrm{C}$, until analysis and utilization.

Identification and determination of essential oils volatile components

Two $\mu$ of each essential oil were injected and analyzed (GC) using a Hewlett Packard model 5890 instrument equipped with a flame ionization detector (FID) and a DB-5 fused silica capillary column $(60 \mathrm{~m} \times 0.32 \mathrm{~mm}$. id and film thickness of $0.32 \mu \mathrm{m})$. The oven temperature was programmed from $60^{\circ} \mathrm{C}$ to $200^{\circ} \mathrm{C}$ with rate $3^{\circ} \mathrm{C} / \mathrm{min}$. Helium $(1 \mathrm{~cm} 3 / \mathrm{min})$ used as a carrier gas. The temperatures of injection port and detector were $220^{\circ} \mathrm{C}$ and $250^{\circ} \mathrm{C}$, respectively. The retention indices (Kovats index) of the separated peaks were calculated (using hydrocarbons C 8-C 23) and their area percentages were calculated with a Hewlett Packard 3396 integrator as reported by Adams (1995).

GC-mass spectroscopic analysis was carried out using a Hewlett-Packard 5972 GC-MS system equipped with the same column and condition used in GC analysis .The ionization voltage was $70 \mathrm{eV}$, mass range $\mathrm{m} / \mathrm{z} 39-400$ amu. Components were identified by matching with data from the library of mass spectra (National Institute of Standard and Technology, NIST) and compared with those authentic compound and published data, as well as on comparison of their indices with those of authentic compounds as mentioned by Adams (1995).

\subsubsection{Biochemical experiment}

The experimental animals were kept in an environmentally controlled room (temperature $25 \circ \pm 2 \mathrm{C}$, humidity: $>60 \%$ ) with regular lightdark cycle. The animals were housed individually in polypropylene aerated cages with screen bottoms and provided diet and water ad libitum. The rats were fed on a basal diet consisted of $21.70 \%$ casein, $53.30 \%$ corn starch, $15 \%$ sucrose , $5 \%$ corn oil , $4 \%$ mineral mixture and $1.00 \%$ vitamin mixture (Tebib et al.,1997) for 10 day. After adaptation 
period, the rats were randomly divided into eight groups (six rats each) as follows: Group 1 (negative control): Animals received a basal diet. Group 2 (positive control): Animals received high fat and cholesterol diet (H.F.C.D) which prepared as basal diet, except that corn starch and corn oil contents were decreased to 39.92 and $2.00 \%$, respectively, and the diet was supplemented with $15 \%$ beef tallow, $1.0 \%$ cholesterol, $0.2 \%$ choline bitartrate and $0.18 \%$ cholic acid, as described by Terpstra et al. (2002). Group 3 (OO): Animals received H.F.C.D and orally provided with $440 \mathrm{mg} / \mathrm{Kg}$ body weight $(\mathrm{BW}) /$ day of orange oil (which contain $400 \mathrm{mg} / \mathrm{Kg}$ BW of limonene). Group 4 (5FOO): Animals received H.F.C.D and orally provided with440mg/Kg BW/ day fivefold orange oil (which contain $320 \mathrm{mg} / \mathrm{Kg} \mathrm{BW}$ of limonene). Group 5 (MO): Animals received H.F.C.D and orally provided with $440 \mathrm{mg} / \mathrm{Kg}$ BW/ day mandarin oil(which contain 280 $\mathrm{mg} / \mathrm{Kg} \mathrm{BW}$ of limonene). Group 6 (5 FMO): Animals received H.F.C.D and orally provided with440mg/Kg BW/ day fivefold mandarin oil (which contain $320 \mathrm{mg} / \mathrm{Kg}$ BW of limonene). Group 7 (LIM): Animals received H.F.C.D and orally provided with $440 \mathrm{mg} / \mathrm{Kg} \mathrm{BW/} \mathrm{day} \mathrm{pure}$ limonene (Ahmad and Beg, 2013). Group 8 (BHT): Animals received H.F.C.D and orally provided with $20 \mathrm{mg} / \mathrm{Kg} \mathrm{BW/} \mathrm{day} \mathrm{synthetic}$ antioxidant (Brewer, 2011).

Animals groups, except negative control group, were fed on a high fat and cholesterol diet (H.F.C.D) for 3 weeks to raise the serum cholesterol level for groups. After 3 weeks, different groups were fed a high fat and cholesterol diets and administrated with different tested original oils, concentrated oils and synthetic antioxidant (BHT) for 4 weeks. The administrations of the original and concentrated oils were done by oral route using a calibrated $1 \mathrm{ml}$ syringe with attached polyethylene canola as described by Vasudeva and Sharma (2012). At the end of experimental period, the rats were fasting over night and sacrificed and then, internal organs were weighed.
The daily dose of original and concentrated oils was specified not to exceed than $1 / 10 \mathrm{LD}_{50}$ of limonene $\left(\mathrm{LD}_{50}=4400 \mathrm{mg} / \mathrm{kg}\right.$ body weight $)$ (Anon, 2009). Original, concentrated and pure limonene was dissolved in $0.5 \mathrm{ml}$ corn oil as a carrier and the doses were applied daily.

At the end of the experiment, feed consumption (intake) ratio was calculated as mentioned by Gorinstein et al. (2007) and Ruangchia and Lien (2012). The body weight gain (BWG, \%) was calculated as follows: Body weight gain $(\%)=($ Final weight - Initial weight / Initial weight) X 100. After 8 weeks, rats were scarified then liver and kidneys were excised immediately then cleaned and weighed. Internal organs percentages (liver, kidneys, heart, brain, spleen and lunges) were calculated according to Atangwho et al. (2012), as follows: Organs weight $(\%)=$ (wt. of organ/ final body wt. of rat) $\times 100$

Blood samples, overnight fasted rats for each group, were taken at the beginning of the experiment and each 15 days interval during experiment period. The blood samples were collected from the eye plexuses by fin glass capillary tubes according to the method of Schermer (1967). The collected blood was put into a dry clean centrifuged glass tube without coagulant to prepare serum sample. Blood was left for $15 \mathrm{~min}$ at room temperature to coagulate then the tube were centrifuged at $3000 \mathrm{rpm}$ for $10 \mathrm{~min}$ and the clean supernatant serum was kept at $-20^{\circ} \mathrm{C}$ to determine blood constituents.

\subsubsection{Biochemical analysis}

Plasma lipid profile was determined. Serum total cholesterol (TC), high density lipoprotein (HDL) and low density lipoprotein (LDL) were determined according to the method of Tietz, (1976). Total lipids (TL) was determined as described by Zollner and Kirsch (1962). Triglycerides (TG) were determined according to the methods of Fossati et al. (1982). Aspartate Aminotransferase (AST) and Alanine Aminotransferase (ALT), as liver function enzymes, were determined colorimetrically as 
described by Sherwin, (1984) and Young (1997), respectively, one unit is defined as $1 \mu \mathrm{mol}$ NADH oxidized per min. Regarding, kidney functions, uric acid was determined as mentioned by Friedman and Young, (2001), while Creatinine was determined in blood serum, according to the method of (Tietz, 1995). Glucose level was determined in blood serum of experimental rats using enzymatic method ascribed by Young et al. (1972).

\subsubsection{Statistical analysis}

The collected data of biological evaluation was statistically analyzed using Analysis of Variance (ANOVA) as mentioned by Rao and Blane (1985). An average of three replicates, unless, otherwise stated, was used in calibrations. The standard deviation (SD) was also calculated.

\section{Results and Discussion}

3.1. Yield and chemical composition of orange and mandarin peel oils and their concentrates

The yield of cold pressed orange and mandarin peel oils was calculated. The results indicated that the orange peels contain about twice the oil yield of mandarin peels, where, they recorded $(0.24 \pm 0.05)$ vs. $(0.12 \pm 0.17) \%$ $(w / w)$. These results confirmed those of orange oil obtained by Kamal et al. (2011) and Badee et al. (2011). Njoroge et al. (2005) recorded $0.13 \%-0.15 \%$ as a range for the oil yield obtained from mandarin peels.

The chemical components of cold pressed orange and mandarin peel oils (OO and MO, respectively) and their fivefold oils, (5FOO and $5 \mathrm{FMO}$, respectively), were fractionated and identified by GC and GC/MS, and the identified components are shown in Table 1.

The results illustrated in Table (1) indicated that orange oil chromatogram included 28 volatile components belong to seven chemical groups. The predominant chemical group was monoterpenes (96.21\%). Five monoterpene compounds were identified in orange oil, the main component is limonene (89.65\%), followed by myrcene(3.95\%). In addition, 6 sesquiterpene hydrocarbons were identified as trace components (representing $0.22 \%$ of oil components) in orange oil. Moreover, three terpene alcohols compounds were identified (as trace compounds), representing $0.80 \%$ of oil components. Furthermore, seven aldehydes compounds representing $1.92 \%$ of orange oil components were identified (as minor compounds), octanal (1.47\%) was the major of them. Orange oil profile components are extended to include one trace oxide component namely, trans-limonene oxide $(0.01 \%)$, and one trace ester component, namely caryophyllene acetate $(0.08 \%)$. Finally, orange oil components included five trace oxygenated sesquiterpenes representing $0.67 \%$ of total oil components.

As for the chemical composition of mandarin oil, the data in Table (1) indicated that, it was consisted of 17 volatile chemical component belong to six chemical groups. Monoterpenes was the major chemical group $(95.12 \%)$, it included 8 volatile chemical components. Limonene and $\gamma$-terpinene were the predominant components, $65.57 \%$ and $23.07 \%$, respectively, while, $\beta$-pinene and myrcene represented minor components in monoterpenes group. However, Sesquiterpenes was a minor chemical group in mandarin oil $(1.4 \%)$ consisted from3 volatile chemical components. Moreover, one compound belongs to alcohols group and another belongs to aldehydes, namely Linalool(1.5\%) and Neral $(0.34 \%)$, respectively, were identified. Three trace esters $(0.5 \%)$ were also detected in mandarin oil.

Fractional distillation is a common industrial method for folding citrus essential oil because of its low cost and the odor profiles of the produced oil. Besides, it is accepted technique in the flavor and fragrance industry as mentioned by Flesher (1994). 
Table 1. Chemical constituents of orange and mandarin oils and their fivefold concentrates by GC/MS

\begin{tabular}{|c|c|c|c|c|c|}
\hline Components & K.I* & OO & $5 F O O$ & MO & 5FMO \\
\hline \multicolumn{6}{|l|}{ Monoterpenes } \\
\hline$\alpha$-Thujene & 929 & -- & -- & 0.45 & -- \\
\hline$\alpha$-Pinene & 937 & 1.31 & 0.09 & 2.07 & -- \\
\hline Sabinene & 978 & 0.76 & 0.07 & 0.22 & -- \\
\hline$\beta$-Pinene & 982 & -- & -- & 1.98 & 0.26 \\
\hline Myrcene & 997 & 3.95 & -- & 1.76 & 0.79 \\
\hline$\Delta$-3-Carene & 1011 & -- & -- & -- & -- \\
\hline$\alpha$-Terpinene & 1018 & 0.54 & 0.52 & -- & -- \\
\hline$\rho$-Cymene & 1027 & -- & -- & 0.30 & 0.08 \\
\hline Limonene & 1036 & 89.65 & 72.99 & 65.57 & 52.95 \\
\hline$\gamma$-Terpinene & 1064 & -- & -- & 23.07 & 22.79 \\
\hline Total & -- & 96.21 & 73.67 & 95.12 & 76.87 \\
\hline \multicolumn{6}{|c|}{ Sesquiterpenes } \\
\hline$\alpha$-Copaene & 1367 & 0.07 & -- & -- & -- \\
\hline$\beta$-Cubabene & 1390 & -- & 0.12 & -- & -- \\
\hline$\beta$ - Caryophyllene & 1418 & -- & 0.48 & -- & 0.12 \\
\hline$\gamma$-Elemenene & 1431 & 0.01 & 0.22 & 0.38 & 1.08 \\
\hline Humulene & 1440 & -- & 0.31 & -- & -- \\
\hline$\beta$-Farnesene & 1458 & 0.01 & 0.1 & 0.74 & 0.42 \\
\hline D-Germarcrene & 1486 & 0.01 & -- & 0.28 & 0.06 \\
\hline Valencene & 1491 & 0.04 & -- & -- & -- \\
\hline$\alpha$-Farnecene & 1508 & -- & 0.80 & -- & 0.05 \\
\hline$\Delta$-Cadinene & 1514 & 0.08 & 0.15 & -- & 2.21 \\
\hline Total & -- & 0.22 & 2.18 & 1.40 & 3.94 \\
\hline \multicolumn{6}{|l|}{ Alcohols } \\
\hline Linalool & 1096 & 0.22 & 0.43 & 1.50 & 4.90 \\
\hline Cis-p-mentha 2,1- dienol & 1121 & 0.31 & -- & -- & 0.24 \\
\hline$\beta$ - Cis-terpeneol & 1142 & -- & 4.27 & -- & 1.53 \\
\hline$\rho$-mentha 1-dien -8- ol & 1149 & -- & -- & -- & 2.49 \\
\hline Terpen-4-ol & 1171 & -- & 0.17 & -- & 0.41 \\
\hline$\alpha$ - Terpineol & 1190 & -- & -- & -- & 0.41 \\
\hline Trans-Carveol & 1218 & 0.27 & 3.01 & -- & 2.96 \\
\hline Geraniol & 1254 & -- & 0.18 & -- & -- \\
\hline Perilla alcohol & 1294 & -- & 0.82 & -- & -- \\
\hline Total & & 0.80 & 8.88 & 1.50 & 12.77 \\
\hline \multicolumn{6}{|l|}{ Phenols } \\
\hline Carvacrol & 1300 & -- & 1.66 & -- & -- \\
\hline Total & -- & -- & 1.66 & -- & -- \\
\hline \multicolumn{2}{|c|}{ Aldehydes } & & & -- & -- \\
\hline Octanal & 1001 & 1.47 & 1.62 & -- & -- \\
\hline Nonanal & 1108 & -- & 0.13 & -- & 0.34 \\
\hline Citronellal & 1159 & 0.03 & 3.60 & -- & 0.60 \\
\hline Decanal $(\mathrm{N})$ & 1204 & 0.26 & 0.76 & -- & 0.74 \\
\hline Neral & 1247 & 0.03 & -- & 0.34 & -- \\
\hline Geranial & 1270 & 0.08 & 2.52 & -- & 0.17 \\
\hline Undecanal & 1306 & 0.01 & 1.56 & -- & 0.48 \\
\hline
\end{tabular}




\begin{tabular}{|c|c|c|c|c|c|}
\hline Dodecanal & 1408 & 0.04 & 0.26 & -- & -- \\
\hline Total & & 1.92 & 10.45 & 0.34 & 2.33 \\
\hline \multicolumn{6}{|l|}{ Oxides } \\
\hline Cis-limonene oxide & 1136 & -- & -- & -- & 0.07 \\
\hline Trans-limonene oxide & 1139 & 0.01 & 1.18 & -- & -- \\
\hline Caryophyllene oxide & 1581 & -- & 0.21 & -- & 0.24 \\
\hline Total & -- & 0.01 & 1.39 & -- & 0.31 \\
\hline \multicolumn{6}{|l|}{ Esters } \\
\hline Citronellyl acetate & 1294 & -- & -- & 0.09 & -- \\
\hline Geranyl acetate & 1383 & -- & 0.73 & 0.11 & 1.05 \\
\hline Methyl N-methyl anthranilate & 1402 & -- & -- & 0.30 & 0.45 \\
\hline Caryophyllene acetate & 1697 & 0.08 & - & - & -- \\
\hline Total & -- & 0.08 & $\mathbf{0 . 7 3}$ & 0.5 & 1.50 \\
\hline \multicolumn{6}{|c|}{ Oxygenated Sesquiterpenes } \\
\hline Z-Nerolidol & 1533 & 0.06 & -- & 0.11 & 1.08 \\
\hline E-Nerolidol & 1564 & 0.12 & 0.77 & - & -- \\
\hline$\beta$-Bisabolol & 1675 & 0.17 & -- & -- & -- \\
\hline$\alpha$-Bisabolol & 1682 & 0.08 & -- & -- & -- \\
\hline$\beta$-Sinensal & 1701 & 0.24 & -- & -- & -- \\
\hline Total & -- & 0.67 & $\mathbf{0 . 7 7}$ & 0.11 & 1.08 \\
\hline \multicolumn{2}{|c|}{ Total Non- oxygenated compounds (\%) } & 96.43 & 75.85 & 96.82 & 80.71 \\
\hline \multicolumn{2}{|c|}{ Total oxygenated compounds (\%) } & 3.48 & 23.98 & 2.45 & $\mathbf{1 7 . 9 4}$ \\
\hline \multicolumn{2}{|c|}{ Total identified components (\%) } & 99.91 & 99.83 & 99.27 & 98.65 \\
\hline
\end{tabular}

* Kovats retention indices calculated for DB-5 capillary column in GC in reference to C8-C23 n-alkane OO: Orange oil, MO: Mandarin oil 5FOO: Five-fold orange oil 5FMO: Five-fold mandarin oil.

Results in Table (1) indicated that the percentage of the major components limonene decreased from $89.65 \%$ in the original orange oil to $72.99 \%$ in five-fold oil (5FOO), $18.58 \%$, decreasing percentage. Otherwise, vacuum distillation process led to decrease limonene, from 65.57 to $52.95 \%$ in five-fold oil (5FMO), $19.24 \%$ decreasing percentage. Whereas, the second major monoterpene components $\gamma$ terpenene, not found in orange oil, slightly affected by distillation $(1.21 \%$, decreasing percentage). The high percentage of limonene in folded orange oil was observed by Vora, et al. (1983), who concentrated orange peels oils of Valencia and Midseason varieties by vacuum distillation to 10 fold and recorded that the percentage of limonene was decreased from 95.17 to $79.91 \%$ in ten-fold orange oil. Although, myrcene was completely disappeared from 5FOO after concentration, three components namely, $\alpha$-Pinene and $\alpha$ Terpinene were variably decreased $(-93.13 \%$, -
$90.79 \%$ and $-3.70 \%$, respectively). As for the rest of monoterpenes in 5FMO. Three components variably decreased, $\beta$-Pinene, Myrcene and p-Cymene (-87.76, -55.11 and $73.33 \%$, respectively). In general, total Monoterpenes in 5fold orange and mandarin oil were reduced by 23.43 and $19.19 \%$, respectively, from their original values after concentration.

Regarding the apparent considerable increases in sesquiterpenes of 5 folded orange and mandarin oils (9.91 times and 2.81times, respectively), it could be noticed that three volatile sesquiterpene compounds present in original orange oil were completely disappeared in concentrated oil. While, $\gamma$ Elemenene, $\beta$-Farnesene and $\Delta$-Cadinen were variably increased after folding process. The increments in sesquiterpenes in the investigated folded oils might be due to the highly boiling range of sesquiterpenes as less volatile components. Hereby, Vora et al. (1983) 
determined the quantitative composition of tenfold orange oil comparing with the original oil and stated that some sesquiterpene components increased after deterpenation process. As for the increments in sesquiterpenes of 5FMO, it might be due to their high boiling range. Concerning the predicted increases in the oxygenated components due to folding process of orange and mandarin oils, total alcoholic components showed the highest increments in5fold orange and mandarin oil(11.1 times and 8.51 times in 5FOO and 5FMO, respectively). It is well known that folding process of orange oil led to disappear one of the three alcoholic volatile components in the original oil, simultaneously, four alcohol components directly appeared in $5 \mathrm{FOO}$ after folding. As for, concentration process of mandarin oil, it led to appear 6 volatile alcohols components which did not present before in the original oils beside the singular original alcohol component, namely; linalool, the characteristic of mandarin oil flavor (Choi and Sawamura, 2002).

With regard to the expected increments in total aldehyde contents of orange and mandarin oils due to folding process, the aldehyde contents increased by 5.44 times and 6.85times in 5FOO and 5FMO, respectively. Furthermore, Phenols components were not found in original orange and mandarin oils, but a unique phenol component was found only in 5 FOO, namely, Carvacrol. As for volatile ester component, trace component was found in original orange oil (Caryophyllene acetate) which disappeared after folding and another ester component (Geranyl acetate) appeared.

It is noteworthy that Methyl-N-methyl anthranilate is the main ester contributes to the overall aroma of mandarin oil as reported by Mazza (1987).

In general, the obtained data (Table 1) indicated that total oxygenated compounds increased 6.89 times and7.32 times in 5FOO and 5FMO, respectively.

\subsection{The biological effects of orange and mandarin oil and their concentrates on hyper-cholesterolimic rats}

The changes in growth performance, internal organs weight $\%$ as well as serum chemistry parameters of hype- cholesterolimic rats were determined after daily oral administrated of orange and mandarin and their concentrated oils for 4 weeks. The $\mathrm{LD}_{50}$ of limonene was taken into consideration. So, all doses didn't exceed (1/10) from $\mathrm{LD}_{50}$ of limonene constituted $4400 \mathrm{mg} / \mathrm{kg}$ BW (440 $\mathrm{mg} / \mathrm{kg} \mathrm{BW}$ ) as recommended by Anon (2009). Regarding growth parameters, results in Table 2 illustrated that there are significant $(p \leq 0.05)$ differences between different groups in the final body weight and body weight gain (BWG) $(\%)$. The significant differences in BWG between positive and negative control groups $(\mathrm{G} 1 \&$ G2) and groups administrated original orange and mandarin oils (G3\&G5) indicated the impact of limonene in reducing obesity. This conclusion ascribed to the decreasing effect in BWG of G7 administrated limonene. The superior depression in BWG showed in group 8 administrated BHT focus the light on the antioxidant activity of BHT and the natural antioxidant, limonene. 
Table 2. Effect of oral administration with orange and mandarin oils and their concentrates on growth performance, internal organs weight $\%$ of hypercholesterolemic rats

\begin{tabular}{|c|c|c|c|c|c|c|c|c|c|}
\hline \multirow{2}{*}{ Parameters } & \multicolumn{8}{|c|}{ Groups of rats } & \multirow{2}{*}{$\underset{* *}{\mathbf{L S D}}$} \\
\hline & G1 & G2 & G3 & G4 & G5 & G6 & G7 & G8 & \\
\hline \multicolumn{10}{|c|}{ Growth performance } \\
\hline $\begin{array}{l}\text { Initial } \\
\text { body } \\
\text { weight }(\mathrm{g})\end{array}$ & $\begin{array}{c}241.75 \\
\mathrm{a} \pm \\
10.53\end{array}$ & $\begin{array}{c}239.50^{\mathrm{a}} \\
\mathrm{b} \pm \\
13.07\end{array}$ & $\begin{array}{c}237.50^{\mathrm{a}} \\
\mathrm{b} \pm \\
14.43\end{array}$ & $\begin{array}{c}248.25 \\
\mathrm{a} \pm \\
13.5\end{array}$ & $\begin{array}{c}222.00 \\
\mathrm{c} \pm \\
18.60\end{array}$ & $\begin{array}{c}222.00 \\
\mathrm{c} \pm \\
13.63\end{array}$ & $\begin{array}{c}256.00 \\
\text { a } \pm \\
12.75\end{array}$ & $\begin{array}{c}231.70 \\
\mathrm{~b} \pm \\
11.78\end{array}$ & 20.42 \\
\hline $\begin{array}{l}\text { Final } \\
\text { body } \\
\text { weight }(g)\end{array}$ & $\begin{array}{c}262.75 \\
\mathrm{a} \pm \\
14.99\end{array}$ & $\begin{array}{c}261.75 \\
\mathrm{a} \pm \\
21.48\end{array}$ & $\begin{array}{c}249.50 \\
\text { ab } \pm \\
19.94\end{array}$ & $\begin{array}{c}264.00 \\
{ }^{\mathrm{a}} \pm \\
14.58\end{array}$ & $\begin{array}{c}229.70 \\
\mathrm{c} \pm \\
23.82\end{array}$ & $\begin{array}{c}238.00 \\
\mathrm{~b} \pm \\
21.35\end{array}$ & $\begin{array}{c}271.00 \\
\mathrm{a} \pm \\
18.99\end{array}$ & $\begin{array}{c}238.00 \\
\mathrm{~b} \pm \\
10.86\end{array}$ & 29.10 \\
\hline $\begin{array}{l}\text { BWG* } \\
(\%)\end{array}$ & $\begin{array}{c}8.68^{\mathrm{a}} \\
\pm 1.80\end{array}$ & $\begin{array}{r}9.29^{\mathrm{a}} \\
\pm 3.21\end{array}$ & $\begin{array}{l}5.05^{\mathrm{bc}} \\
\pm 1.46\end{array}$ & $\begin{array}{l}6.34^{\mathrm{ab}} \\
\pm 2.59\end{array}$ & $\begin{array}{c}3.46^{\mathrm{c}} \\
\pm 2.41\end{array}$ & $\begin{array}{r}7.20^{\mathrm{a}} \\
\pm 6.27\end{array}$ & $\begin{array}{c}5.85^{\mathrm{b}} \\
\pm 2.39\end{array}$ & $\begin{array}{c}2.69^{\mathrm{d}} \\
\pm 3.24\end{array}$ & 4.20 \\
\hline $\begin{array}{l}\text { Food } \\
\text { intake } \\
\text { (g/rat/day) }\end{array}$ & $\begin{array}{l}14.99^{\mathrm{a}} \\
\pm 3.88\end{array}$ & $\begin{array}{l}15.13^{\mathrm{a}} \\
\pm 3.24\end{array}$ & $\begin{array}{l}15.48^{\mathrm{a}} \\
\pm 4.21\end{array}$ & $\begin{array}{l}15.11^{\mathrm{a}} \\
\pm 4.36\end{array}$ & $\begin{array}{l}15.57^{\mathrm{a}} \\
\pm 4.10\end{array}$ & $\begin{array}{l}15.26^{\mathrm{a}} \\
\pm 4.34\end{array}$ & $\begin{array}{l}15.88^{\mathrm{a}} \\
\pm 3.52\end{array}$ & $\begin{array}{l}15.90^{\mathrm{a}} \\
\pm 3.84\end{array}$ & 0.00 \\
\hline \multicolumn{10}{|c|}{ Internal organs weight (\%) } \\
\hline Liv & $\begin{array}{l}2.89^{\mathrm{c}} \\
\pm 0.19\end{array}$ & $\begin{array}{l}4.06^{a b c} \\
\pm 0.15\end{array}$ & $\begin{array}{l}4.72^{a} \\
\pm 0.42\end{array}$ & $\begin{array}{l}4.21^{\mathrm{ab}} \\
\pm 0.23\end{array}$ & $\begin{array}{l}4.67^{\mathrm{a}} \\
\pm 0.52\end{array}$ & $\begin{array}{r}4.45^{\mathrm{a}} \\
\pm 0.53\end{array}$ & $\begin{array}{c}3.95^{\mathrm{b}} \\
\pm 0.51\end{array}$ & $\begin{array}{l}3.81 \mathrm{bc} \\
\pm 0.32\end{array}$ & 0.73 \\
\hline Kidneys & $\begin{array}{l}0.59^{\mathrm{a}} \\
\pm 0.18 \\
\end{array}$ & $\begin{array}{l}0.56^{\mathrm{a}} \\
\pm 0.09 \\
\end{array}$ & $\begin{array}{l}0.59^{\mathrm{a}} \\
\pm 0.05 \\
\end{array}$ & $\begin{array}{l}0.53^{\mathrm{a}} \\
\pm 0.05 \\
\end{array}$ & $\begin{array}{l}0.62^{\mathrm{a}} \\
\pm 0.02 \\
\end{array}$ & $\begin{array}{l}0.61^{\mathrm{a}} \\
\pm 0.07 \\
\end{array}$ & $\begin{array}{l}0.58^{\mathrm{a}} \\
\pm 0.05 \\
\end{array}$ & $\begin{array}{r}0.49^{\mathrm{a}} \\
\pm 0.09 \\
\end{array}$ & 0.00 \\
\hline Heart & $\begin{array}{l}0.33^{\mathrm{a}} \\
\pm 0.07 \\
\end{array}$ & $\begin{array}{l}0.32^{\mathrm{a}} \\
\pm 0.06 \\
\end{array}$ & $\begin{array}{l}0.28^{\mathrm{a}} \\
\pm 0.04 \\
\end{array}$ & $\begin{array}{l}0.28^{\mathrm{a}} \\
\pm 0.02 \\
\end{array}$ & $\begin{array}{l}0.26^{\mathrm{a}} \\
\pm 0.04\end{array}$ & $\begin{array}{r}0.25^{\mathrm{a}} \\
\pm 0.03\end{array}$ & $\begin{array}{l}0.26^{\mathrm{a}} \\
\pm 0.04\end{array}$ & $\begin{array}{l}0.27^{\mathrm{a}} \\
\pm 0.06\end{array}$ & 0.00 \\
\hline Brain & $\begin{array}{r}0.61^{\mathrm{a}} \\
\pm 0.14 \\
\end{array}$ & $\begin{array}{l}0.49^{\mathrm{a}} \\
\pm 0.10 \\
\end{array}$ & $\begin{array}{l}0.57^{\mathrm{a}} \\
\pm 0.05 \\
\end{array}$ & $\begin{array}{l}0.56^{\mathrm{a}} \\
\pm 0.01 \\
\end{array}$ & $\begin{array}{r}0.58^{\mathrm{a}} \\
\pm 0.03 \\
\end{array}$ & $\begin{array}{r}0.59^{\mathrm{a}} \\
\pm 0.02 \\
\end{array}$ & $\begin{array}{r}0.56^{\mathrm{a}} \\
\pm 0.06 \\
\end{array}$ & $\begin{array}{r}0.52^{\mathrm{a}} \\
\pm 0.08 \\
\end{array}$ & 0.00 \\
\hline Spleen & $\begin{array}{r}0.24^{\mathrm{a}} \\
\pm 0.13 \\
\end{array}$ & $\begin{array}{l}0.30^{\text {a }} \\
\pm 0.10 \\
\end{array}$ & $\begin{array}{l}0.33^{\text {a }} \\
\pm 0.09\end{array}$ & $\begin{array}{l}0.23^{\mathrm{a}} \\
\pm 0.04\end{array}$ & $\begin{array}{l}0.29^{\mathrm{a}} \\
\pm 0.04\end{array}$ & $\begin{array}{r}0.29^{\mathrm{a}} \\
\pm 0.07\end{array}$ & $\begin{array}{r}0.26^{\mathrm{a}} \\
\pm 0.08 \\
\end{array}$ & $\begin{array}{l}0.33^{\mathrm{a}} \\
\pm 0.05^{2}\end{array}$ & 0.00 \\
\hline & $\begin{array}{c}0.65^{\mathrm{a}} \\
\pm 0.07\end{array}$ & $\begin{array}{l}0.62^{\mathrm{a}} \\
\pm 0.08\end{array}$ & $\begin{array}{l}0.63^{\mathrm{a}} \\
\pm 0.06\end{array}$ & $\begin{array}{l}0.57^{\mathrm{a}} \\
\pm 0.03\end{array}$ & $\begin{array}{l}0.63^{\mathrm{a}} \\
\pm 0.06\end{array}$ & $\begin{array}{l}0.59^{\mathrm{a}} \\
\pm 0.05\end{array}$ & $\begin{array}{l}0.51^{\mathrm{a}} \\
\pm 0.07\end{array}$ & $\begin{array}{l}0.55^{\mathrm{a}} \\
\pm 0.03\end{array}$ & 0.00 \\
\hline
\end{tabular}

Means ( $\mathrm{n}=6$ rats \pm SD) with the same letter between rows are not significantly different at $\mathrm{P} \geq 0.05$.

G1 : Basal diet (negative control). G2 : High fat diet $+1 \%$ cholesterol (HFCD) (positive control).

G3 : HFCD + $440 \mathrm{mg}$ OO contain $400 \mathrm{mg} / \mathrm{Kg} \mathrm{BW}$ of limonene daily. G4 : HFCD + $440 \mathrm{mg} 5 \mathrm{FOO}$ contain $320 \mathrm{~g} / \mathrm{Kg} / \mathrm{BW}$ of limonene daily. G5 : HFCD + $440 \mathrm{mg}$ MO contain $280 \mathrm{mg} / \mathrm{Kg} \mathrm{BW}$ of limonene daily. G6 : HFCD + $440 \mathrm{mg} 5 \mathrm{FMO}$ contain $230 \mathrm{~g} / \mathrm{Kg} / \mathrm{BW}$ of limonene daily.G7 : HFCD + $440 \mathrm{mg} / \mathrm{Kg} / \mathrm{BW}$ pure limonene daily. G8 : HFCD +20 mg $\mathrm{BHT} / \mathrm{Kg} \mathrm{BW/daily.}$

$*$ Body weight gain $\%=($ Final weight - Initial weight $/$ Initial weight $) \mathrm{X} 100 . \quad * *$ Least significant differences.

Our findings are not in agreement with Ruangchai and Lien, (2012)who found that limonene didn't affect the body weight gain of rats. Jing et al. (2013) reported that d-limonene did not prevent body weight gain of mice group fed on high fat diet supplemented with $0.6 \mathrm{~g} \mathrm{~d}-$ limonene $/ \mathrm{Kg} / \mathrm{BW}$, in compared with groups fed on high fat diet as a positive control. Concerning the internal organs weight $(\%)$ of rat groups, the highest liver weight \% was observed in the groups of rats G3 \& G5, where, they recorded 4.72 and $4.67 \%$, respectively. On 
the other hand, the lowest (2.89\%) was recorded by the negative control group (G1) followed by (G8). The rats fed on high fat diet have increased in liver weight by fat deposition on their bodies (Milagro et al., 2006). Slightly non significant differences were noticed in liver weight $\%$ among rat groups administrated original, concentrated orange or mandarin oils (G3, G4 and G5 or G6).

No significant differences $(p \leq 0.05)$ were observed among rat groups (G2) and (G7) fed on the same diet plus pure limonene (440 $\mathrm{mg} / \mathrm{Kg} \mathrm{BW}$ ). Thus, pure limonene component didn't affect fat accumulation in adipose tissues or increased fat cells numbers and size. No significant $(\mathrm{p} \leq 0.05)$ differences in kidneys, heart, brain, lungs and spleen weight \% among rats fed $(\mathrm{P} \leq 0.05)$ on a basal diet and those groups fed on high fat diet and cholesterol and orally administrated with the investigated oils. These results are in agreement with those of Osfor et al. (2013) who found that the increment in heart and spleen weight of hypercholesterolemic rats or that supplemented by Citrus aurantium albedo powder compared with basal diet rats, was not significant.

On the other hand, serum lipid profile of rats was determined and the results are shown in Table (3). Results indicated that the serum total lipids (TL) level of rats, fed with different experimental diets, was significantly increased $(\mathrm{p} \leq 0.05)$ in positive control group (G2) fed with HFCD as compared with negative control (G1 given a basal diet). It could be noticed that (G6) had a lower total lipids level (332.67 $\mathrm{mg} / \mathrm{dL}$ ) than that received HFCD, (G2) which gave the highest TL level $(502.24 \mathrm{mg} / \mathrm{dL})$. The results concerning the lowering effect of TL by limonene are supported with the findings of Ruangchai and Lien (2012) and Ahmad and Beg (2013). So, it could be noticed that, serum TL level decreased after oral administration of experimental obese rats groups fed with H.F.C.D for G3, G4, G5 and G6. Moreover, the highest depression effect of TL could be noticed in G3, followed with G6, which could be attributed to the effect of limonene beside other monoterpenes found in orange and folded mandarin oils.

The superior serum total cholesterol (TC) level $(143.31 \mathrm{mg} / \mathrm{dL})$ was observed in group fed with H.F.C.D and (0.2 ppm) BHT (G8) followed by positive control $\mathrm{G} 2(132.96 \mathrm{ml} / \mathrm{dL})$ with no significant $(\mathrm{p} \leq 0.05)$ differences between them. The average TC levels after four weeks in the cholesterol-fed groups (G3, G4, G5, G6 \& G7) showed significantly $(\mathrm{p} \leq 0.05)$ decrement compared with positive control G2. The results indicated that the decrement of TC level among cholesterol-fed groups did not connect with amount of limonene consumed by rat groups only but may be related with the other minor components associated with limonene and subsequently shared with limonene as antioxidant potency (synergistic effect) as mentioned by Russo, et al. (2013) and Sharifi-Rad, et al. (2017). Similar data indicated that each of orange and mandarin oils and their concentrates had considerable reduction effects against the increase of serum total cholesterol. The reduction in TC and TG could be explained by the inhibition of two key enzymes in the regulation of cholesterol synthesis: HMG-CoA reductase and Acyl-Co A: Cholesterol acyl transferase (ACAT) (Kim et al., 2003). Indeed, limonene inhibited hepatic cholesterol biosynthesis and esterification (Clegg et al., 1980). The blockage of cholesterol synthesis by an inhibitor of HMGCoA reductase (Elegbede et al., 1984). Consequently, limonene reduces synthesis of HMG-CoA reductase at a post-transcriptional level (Clegg et al., 1980). Our findings also are in harmony with those reported by Lee, et al., (2018), who found antioxidative and cholesterol-lowering activities of lemon essential oil $(67.57 \%$ limonene $)$ in hypercholesterolemia-induced rabbits, evidenced by its inhibition effects on LDL oxidation and lipid peroxidation and preventive effects against erythrocyte deformation and aortic intimal proliferation. Several mechanisms for limonene protection in biological systems, which include the 
deactivation of electronically activated species such as singlet oxygen and the deactivation of reactive chemical species, such as peroxyl or alkoxyl radicals that can be generated within cells, might be precluded the initiation of harmful oxidative reactions (Cao et al., 1993).
In general, all tested groups administrated with orange and mandarin oils and their concentrates, showed improve in HDL levels nearly and better than negative control.

Table 3. Effect of oral administration with orange and mandarin oils and their concentrates on lipid profile and kidney functions of hyper-cholesterolemic rats.

\begin{tabular}{|c|c|c|c|c|c|c|c|c|c|}
\hline \multirow{2}{*}{ Parameters } & \multicolumn{8}{|c|}{ Groups of rats } & \multirow{2}{*}{ LSD* } \\
\hline & G1 & G2 & G3 & G4 & G5 & G6 & G7 & G8 & \\
\hline $\begin{array}{l}\text { Total lipids } \\
\text { (mg/dL) }\end{array}$ & $\begin{array}{c}292.31 \\
\mathrm{~cd} \pm \\
26.57\end{array}$ & $\begin{array}{c}502.24 \\
\text { ab } \pm \\
91.73\end{array}$ & $\begin{array}{c}209.45 \\
\mathrm{~d} \pm \\
30.96\end{array}$ & $\begin{array}{c}364.71 \\
\text { cd } \pm \\
42.12\end{array}$ & $\begin{array}{c}403.14 \\
\text { abc } \\
\pm 56.66\end{array}$ & $\begin{array}{c}261.25 \\
\text { cd } \pm \\
122.62\end{array}$ & $\begin{array}{c}332.67 \\
\mathrm{~cd} \pm \\
95.47\end{array}$ & $\begin{array}{c}513.77 \\
\mathrm{a} \pm \\
157.24\end{array}$ & 146.80 \\
\hline $\begin{array}{l}\text { Total } \\
\text { cholesterol } \\
(\mathrm{mg} / \mathrm{dL})\end{array}$ & $\begin{array}{l}80.21^{\mathrm{d}} \\
\pm 5.43\end{array}$ & $\begin{array}{c}132.96 \\
\mathrm{a} \pm \\
35.21\end{array}$ & $\begin{array}{l}94.56^{\mathrm{c}} \\
\pm 7.83\end{array}$ & $\begin{array}{c}114.85 \\
\mathrm{bc}_{ \pm} \\
28.22\end{array}$ & $\begin{array}{l}116.38^{b} \\
\pm 19.17\end{array}$ & $\begin{array}{c}108.28 \\
\mathrm{~b} \pm \\
19.17\end{array}$ & $\begin{array}{l}109.79^{\mathrm{b}} \\
\pm 16.02\end{array}$ & $\begin{array}{l}143.31^{\mathrm{a}} \\
\pm 40.11\end{array}$ & 40.54 \\
\hline $\begin{array}{l}\text { Triglycerides } \\
\text { (mg/dL) }\end{array}$ & $\begin{array}{c}89.28 \\
\mathrm{ab} \pm \\
5.94 \\
\end{array}$ & $\begin{array}{l}83.51 \\
\text { ab } \pm \\
19.11 \\
\end{array}$ & $\begin{array}{c}49.14 \\
{ }^{c} \pm \\
6.95 \\
\end{array}$ & $\begin{array}{c}63.61 \\
\mathrm{~b} \pm \\
18.58 \\
\end{array}$ & $\begin{array}{c}63.29 \\
\mathrm{~b} \pm 9.55\end{array}$ & $\begin{array}{c}55.00 \\
{ }^{\mathrm{c}} \pm \\
11.40 \\
\end{array}$ & $\begin{array}{l}67.85^{b} \\
\pm 19.67\end{array}$ & $\begin{array}{l}101.58^{a} \\
\pm 22.50\end{array}$ & 26.12 \\
\hline $\begin{array}{l}\text { HDL } \\
\text { (mg/dL) }\end{array}$ & $\begin{array}{c}39.65^{\mathrm{b}} \\
\pm \\
12.35\end{array}$ & $\begin{array}{l}27.30^{c} \\
\pm 4.05\end{array}$ & $\begin{array}{c}45.06 \\
\mathrm{ab} \pm \\
6.95\end{array}$ & $\begin{array}{c}40.73 \\
b \pm \\
6.03 \\
\end{array}$ & $\begin{array}{l}50.48^{a} \\
\pm 2.08\end{array}$ & $\begin{array}{c}37.91 \\
\text { bc } \\
\pm 2.62\end{array}$ & $\begin{array}{c}42.03 \\
a b c \\
\pm 19.67 \\
\end{array}$ & $\begin{array}{l}49.61^{\mathrm{a}} \\
\pm 6.82\end{array}$ & 11.21 \\
\hline $\begin{array}{l}\text { LDL } \\
\text { (mg/dL) }\end{array}$ & $\begin{array}{l}22.70^{c} \\
\pm 8.18\end{array}$ & $\begin{array}{c}88.95^{\mathrm{a}} \\
\pm \\
33.59\end{array}$ & $\begin{array}{c}39.66 \\
\mathrm{~b} \pm \\
4.20\end{array}$ & $\begin{array}{l}61.39 \\
\mathrm{ab} \pm \\
35.17\end{array}$ & $\begin{array}{l}53.24^{\mathrm{abc}} \\
\pm 12.42\end{array}$ & $\begin{array}{c}59.35^{\mathrm{ab}} \\
\pm \\
22.33\end{array}$ & $\begin{array}{l}54.19^{a b c} \\
\pm 14.72\end{array}$ & $\begin{array}{l}73.37^{\mathrm{a}} \\
\pm 29.61\end{array}$ & 29.12 \\
\hline $\begin{array}{l}\text { Urea } \\
(\mathrm{mg} / \mathrm{dL})\end{array}$ & $\begin{array}{l}46.05^{\mathrm{a}} \\
\pm 4.44\end{array}$ & $\begin{array}{c}35.95 \\
\mathrm{ab}_{ \pm} \pm 7.24\end{array}$ & $\begin{array}{c}31.53 \\
\mathrm{~b}_{ \pm} \\
5.30\end{array}$ & $\begin{array}{c}31.27 \\
\mathrm{~b} \pm \\
5.49 \\
\end{array}$ & $\begin{array}{l}26.90^{c} \\
\pm 1.46\end{array}$ & $\begin{array}{c}28.33 \\
b c \\
\pm 5.59\end{array}$ & $\begin{array}{l}38.06^{\mathrm{a}} \\
\pm 9.89\end{array}$ & $\begin{array}{l}41.42^{\mathrm{a}} \\
\pm 2.62\end{array}$ & 8.24 \\
\hline $\begin{array}{l}\text { Creatinine } \\
\text { (mg/dL) }\end{array}$ & $\begin{array}{c}0.41^{\mathrm{a}} \pm \\
0.08\end{array}$ & $\begin{array}{l}0.40^{\mathrm{a}} \\
\pm 0.03\end{array}$ & $\begin{array}{l}0.35^{\mathrm{a}} \\
\pm 0.02\end{array}$ & $\begin{array}{l}0.47^{\mathrm{a}} \\
\pm 0.11\end{array}$ & $\begin{array}{c}0.40^{\mathrm{a}} \pm \\
0.03\end{array}$ & $\begin{array}{r}0.48^{\mathrm{a}} \\
\pm 0.03\end{array}$ & $\begin{array}{c}0.44^{\mathrm{a}} \pm \\
0.14\end{array}$ & $\begin{array}{c}0.42^{\mathrm{a}} \pm \\
0.09\end{array}$ & 0.00 \\
\hline
\end{tabular}

Means $(n=6$ rats $\pm S D)$ with the same letter between rows are not significantly different at $P \geq 0.05$.

G1 : Basal diet (negative control). G2 : High fat diet $+1 \%$ cholesterol (HFCD) (positive control).

G3 : HFCD + $440 \mathrm{mg}$ OO contain $400 \mathrm{mg} / \mathrm{Kg} \mathrm{BW}$ of limonene daily. G4 : HFCD + $440 \mathrm{mg} 5 \mathrm{FOO}$ contain $320 \mathrm{~g} / \mathrm{Kg} / \mathrm{BW}$ of limonene daily. G5 : HFCD + $440 \mathrm{mg} \mathrm{MO}$ contain $280 \mathrm{mg} / \mathrm{Kg} \mathrm{BW}$ of limonene daily. G6 : HFCD + $440 \mathrm{mg} 5 \mathrm{FMO}$ contain $230 \mathrm{~g} / \mathrm{Kg} / \mathrm{BW}$ of limonene daily.

G7 : HFCD + $440 \mathrm{mg} / \mathrm{Kg} / \mathrm{BW}$ pure limonene daily. $\quad \mathbf{G 8}: \mathrm{HFCD}+20 \mathrm{mg} \mathrm{BHT} \mathrm{/Kg} \mathrm{BW/daily.}$

* Least significant differences.

With regard to findings of LDL level, no significant $(p \leq 0.05)$ differences were observed among groups fed with HFCD and administrated with orange and mandarin oils (G3and G5), five-fold orange and mandarin
oils(G4 and G6), and limonene (G7), of varying of limonene content, in these oils the lowest LDL level was noticed in the group original orange oil (G3). The level of LDL in serum of G5, rats administrated mandarin oil 
(280 mg limonene content) compared with the group of rats $\mathrm{G} 7$ administrated pure limonene (440 mg limonene content) was not significant. Also, no significant difference between LDL level of rats group G4, administrated five-fold orange oil, $320 \mathrm{mg}$ limonene content, and rats of group G6 administrated five-fold mandarin oil $(0.23 \mathrm{~g} / \mathrm{kg}$ limonene $)$, indicated that the depression in LDL levels among the tested groups was not directly related to the given amount of limonene.

Triglycerides (TG) level of hypercholesterolemic rats groups administrated with sweet orange oil G3, and five-fold mandarin oil G6 remained lower than that of rats orally received five-fold orange oil G4 and mandarin oil G5. Also, these groups were significantly lower in triglycerides content than pure limonene group G7 administrated with (440 mg limonene content). These results indicated that there was no liner relation among serum triglyceride level in hyper-cholesterolemic rats groups and amount of limonene orally consumed. Jing et al. (2013) showed that Dlimonene $(5 \%)$ as supplementation in mice diet reduced TG by $36.1 \%$ and lowered LDL by $20.4 \%$ and increased HDL by $18.3 \%$ compared to the obese mice. Also, it reduces lipid deposition in the hepatic tissue compared to high fat diet fed mice. Thus, it could be noticed that d-limonene prevent lipid accumulation in obese mice liver and reduce the risk association with metabolic function of lipids in HFD obese mice (Jing et al. 2013). The supplementation of the diet with d-limonene at $0.2 \%$ significantly reduced serum cholesterol and triglycerides concentration of rats and increase the antioxidant activity of the Serum Superoxide Dismutase, the catalase and the Glutathione Peroxidase as endogenous liver enzymes compared with basal diet group.

The data showed that there were significant decreases in serum urea values between the negative control (G1) and the groups of rats fed on orange oil (G3), fivefold orange oil (G4), mandarin oil (G5), fivefold mandarin oil (G6). These results, besides the non significant changes in creatinine levels (Table, 3) proved that orange and mandarin oils and their concentrates didn't have a detrimental effect on the kidney functions, but the opposite may be true. Similar findings also indicated that dlimonene component was not solely responsible for the slight improvement of kidney functions. The higher of serum urea level in negative control rats group than the level of urea in positive control groups also was observed by Kanthlal et al. (2012), who found that the rats fed on high fat and cholesterol diet was lower in serum urea level than those fed on basal diets. The capacity of the hepatocytes in obese rats to synthesize urea from precursors is decreased and the uptake of amino acid by liver and the hepatic activity of the enzymes of urea cycle are also decreased (Barber et al., 1985). Hence, there will be a decrease in the urea level in obese rats.

\subsection{Effects of orange and mandarin oil and their concentrates on liver function enzymes of hyper-cholesterolimic rats}

From the results in Fig. (1), the lowest level of AST enzyme was in the negative control group of rats (G1, $12.00 \mathrm{U} / \mathrm{L})$, while the highest level was with the positive group fed with high fat diet $+1 \%$ cholesterol $(\mathrm{G} 2,39.33 \mathrm{U} / \mathrm{L})$. It is important to observe that addition of 5fold orange oil (G4) or limonene(G7) strongly prevent the increase of AST level in both rat groups with non significant differences among them and the negative control group (G1). It was observed that all tested essential oils and BHT in groups of rats G3, G5, G6 and G8 considerably decreased AST levels but to slightly higher level than G1. No significance $(\mathrm{p} \leq 0.05)$ differences were observed among groups fed with orange, mandarin oils, their concentrates and pure limonene in spite of varying of amount of limonene administrated. Thus, the variations of the amount of limonene consumed by rats in different groups don't affect the amount released of AST. 


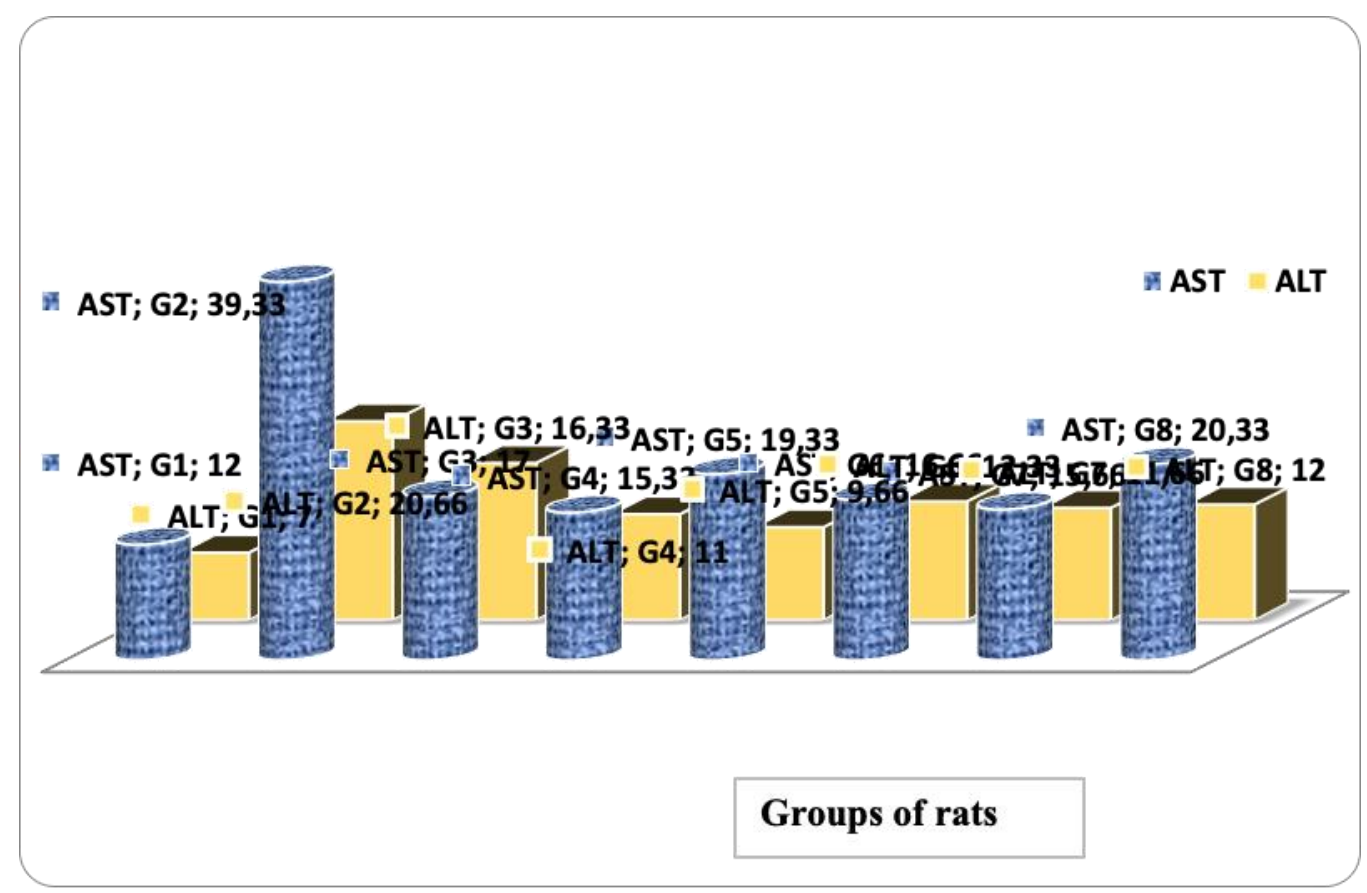

Fig. 1. Effect of oral administration with orange and mandarin oils and their concentrates on liver function enzymes of hyper-cholesterolemic rats.

On the other hand, the five-fold orange and mandarin oils groups (G4 and G6) was more effective in reducing AST activity in serum than their original oils (G3 and G5). A high significant protective effect was noticed of mandarin oil (G5) against release of ALT compared with the positive control G2. All other additions significantly reduced ALT levels, but to lower extents (G3, G4, G6, G7 and G8). Some components of certain species of citrus fruit such as Bergamot orange, as limonene and $\alpha$-pinene, have hepatoprotective effects as published by Ozbek, et al. (2005). In this connection, Karaca, et al. (2005) examined hepato-protective activity of Bergamot essential compared with the positive control G2. All other additions significantly reduced ALT levels, but to lower extents (G3, G4, G6, G7 and G8).
It was mentioned that some components of certain species of citrus fruit such as Bergamot orange, as limonene and $\alpha$-pinene, have hepatoprotective effects as published by Ozbek, et al. (2005). In this connection, Karaca, et al. (2005) examined hepato-protective activity of Bergamot essential oil, limonene (40\%) and linalool $(8 \%)$, on carbon tetrachloride-induced hepatotoxicity in rats and reported that Bergamot oil reduced the serum ALT level but did not affect the AST level.

\subsection{Effects of orange and mandarin oil and their concentrates on serum glucose of hyper-cholesterolimic rats}

The data presented in Fig. 2 showed that no significant $(\mathrm{p} \leq 0.05)$ differences were noticed between the negative control group (G1), pure limonene group (G7) and BHT group (G8) 


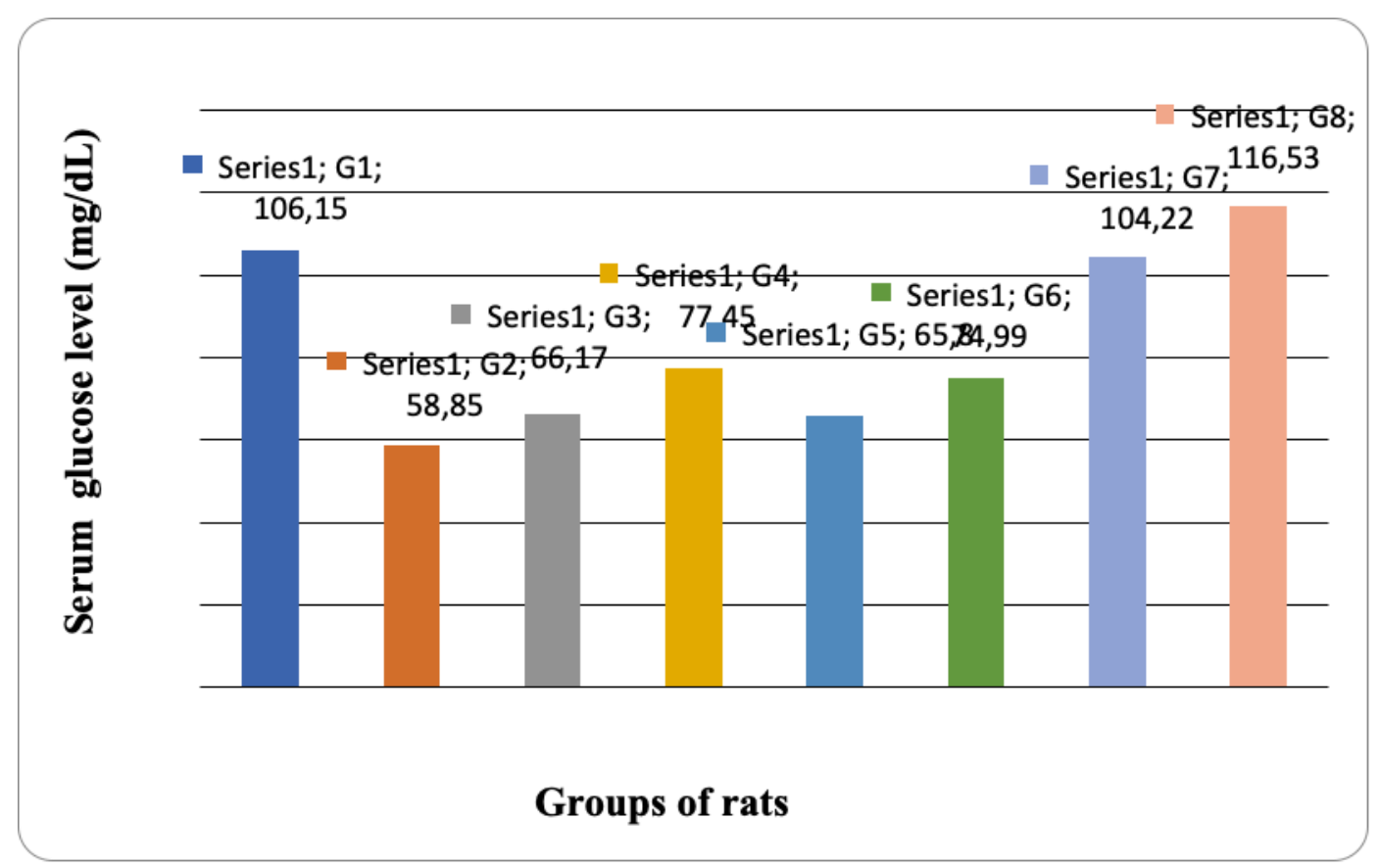

Fig. 2. Effect of oral administration with orange and mandarin oils and their concentrates on serum glucose level of hyper-cholesterolemic rats.

Meanwhile, significant decrements in serum glucose level were detected in the five remaining groups fed on orange oil, mandarin oil or their concentrates (G2, G3, G4, G5 and G6), comparing with the above mentioned three groups (G1, G7 and G8). It's noteworthy to observe that rats fed with orange oil, mandarin oil and their concentrates did not change serum glucose level whether over the normal range $50-136 \mathrm{mg} / \mathrm{dL}$ (Gad, 2007).

In general, it's clear that rats fed with orange oil, mandarin oil, and their concentrates tended to show significant decreases in serum glucose levels. More et al., (2014) demonstrated that the combination of limonene and linalool can function very effectively against serum glucose level in diabetic rats by act in synergistic manner.

\section{Conclusions}

The deterpenation process reduced the percentages of limonene in five fold orange and mandarin oils. Oral administration with orange and mandarin oils and their concentrates, for hypercholesterolemic rats for four weeks exhibited improvement in HDL levels nearly to normal level compared to the negative control, however, the decrement of serum cholesterol level among cholesterol-fed groups did not correlate with the amount of limonene consumed by rats and may be related to other minor components associated with limonene and shared in the antioxidant effect. The efficiency of folded oils on hypocholesterolemic rats did not affect by decreasing limonene by deterpenation process.

\section{References}

Adams, P. R. (1995). Identification of essential oil components by Gas Chromatography / Mass Spectroscopy. Allured: Carol Stream, IL, USA.

Ahmad, M. M., Rehman, S. U. (2006). Sensory evaluation of citrus peel essential oils as flavouring agents in various food products. Journal of Agricultural Research, 44(4), 325-333.

Ahmad, S., Beg, Z. H. (2013). Hypolipidemic and antioxidant activities of thymoquinone 
and limonene in atherogenic suspension fed rats. Food Chemistry, 138(2-3), 1116-1124.

Anon. (2009). Screening-level hazard characterization monoterpene hydrocarbons category U.S. Environmental Protection Agency Hazard Characterization Document September.

Atangwho, I. J., Emmanuel E. E., Uti D. E., Obi A. U., Asmawi M. Z., Ahmad M. (2012). Biochemical and histological impact of Vernonia amygdalina supplemented diet in obese rats. Saudi Journal of Biological Sciences, 19, 385392.

Badee, A. Z. M., Helmy, S. A., Morsy, N. F. S.(2011). Utilization of orange peel in production of $\alpha$-terpineol by Penicillium digitatum (NRRL1202). Food Chemistry, 126, 849-854.

Barber, T., Vina, J. R., Cabo, J. (1985). Decreased urea synthesis in cafeteria-dietinduced obesity in the rat. Biochemical Journal, 230(3), 675-681.

Baser K. H. C., Buchbauer G. (2010). Handbook of Essential Oils: Science, Technology and Applications. CRC Press, Boca Raton, FL, USA.

Bettini, M. F. M. (2007). Purification of orange peel oil and oil phase by vacuum distillation. In Functional food ingredients and nutraceutical processing and technologies. CRC Press, Taylor and Franicis group. Sited from www.taylorandfrancis.com.

Bourgou, S., Rahali, F. Z., Ourghemmi, I., Tounsi, M. S. (2012). Changes of peel essential oil composition of four Tunisian Citrus during fruit maturation. The Scientific World Journal, Article ID 528593, 10 pages.

Brewer, M. S. (2011). Natural antioxidants, sources, compounds, mechanisms of action, and potential applications. Comprehensive Reviews in Food Science and Food Safety, 10(4), 221-247.

Brunzell, J. D., Davidson, M., Furberg, C. D., Goldberg, R. B., Howard, B. V., Stein, J.
H., Witztum, J. L. (2008). Lipoprotein management in patients with cardiometabolic risk-consensus statement from the American Diabetes Association and the American College of Cardiology Foundation. Diabetes Care, 31(4),811-822.

Cao, G., Alessio, M. H., Culter, G. R. (1993). Oxygen-radical absorbance capacity assay for antioxidants. Free Radical Biology and Medicine, 14 (3):303-311.

Choi, H. S., Sawamura, M. (2002). Comparison of the cold-pressed peel oil composition between Korean and Japanese Satsuma mandarin (Citrus unshiu Marcov. Forma Miyagawawase) by GC, GC-Mass and GCO. Journal of Food Science and Nutrition, 7(1), 5-11.

Clegg, R. J., Middleton, B., Bell, G. D., White, D. A. (1980). Inhibition of hepatic cholesterol synthesis and 3-hydroxy-3methylglutaryl-CoA reductase by mono and bicyclic monoterpenes administered in vivo. Biochemical Pharmacology, 29, 21252127.

Elegbede, J. A., Elson, C. E., Qureshi, A. (1984). Inhibition of DMBA induced mammary cancer by the monoterpene dlimonene. Carcinogenesis, 5(5), 661-664.

Ferhat, A., Meklati, M. Y. B., Chemat, F. (2007). Comparison of different isolation methods of essential oil from Citrus fruits: cold pressing, hydrodistillation and microwave 'dry' distillation. Flavour and Fragrance Journal, 22, 494-504.

Fleisher, A. (1994). Citrus hydrocarbon-free essential oils. Perfume and Flavorist, 19(1), 11-15.

Fossati, P., Principe, L. (1982). Serum Triglycerides determined calorimetrically with an enzyme that produces hydrogen peroxide. Clinical Chemistry, 28(10), 20772080.

Friedman, R. B., Young, D. S. (2001). Effects of Disease on Clinical Laboratory Tests, 4th Edition, A.A.C.C Press, Washington, D.C. USA. 
Gad, S. C. (2007). Animal Models in Toxicology. (pp. 196-197).CRC Press, Boca Raton.

Gorinstein, S., Leontowicz, H., Leontowicz, M., Krzeminski, R., Gralak, M., Jastrzebski, Z., Park, Y. S., Jung, S T., Kang, S. G., Trakhtenberg, S. (2007). Effect of hesperidin and naringin on the plasma lipid profile and plasma antioxidant activity in rats fed a cholesterol-containing diet. Journal of the Science of Food and Agricultural, 87,1257-1262.

Jing, L., Zhang, Y., Fan, S., Gu, M., Guan, Y., Lu, X., Huang, C., Zhou, Z. (2013). Preventive and ameliorating effects of citrus D-limonene on dyslipidemia and hyperglycemia in mice with high-fat dietinduced obesity. European Journal of Pharmacology, 715, 46-55.

Kamal, G. M., Anwar, F., Hussain, A. I., Sarri, N., Ashraf, M. Y. (2011). Yield and chemical composition of citrus essential oils as affected by drying pretreatment of peels. International Food Research Journal, 18(4), 1275-1282.

Kanthlal, S. K., Suresh, V., Arunachalam, G., Royal, F. P., Kameshwaran, S. (2012). Anti-obesity and hypolipidemic activity of methanol extract of Tabernaemontana divaricata on atherogenic diet induced obesity in rats. International Research Journal of Pharmacy (IRJP), 3(3), 157161.

Karaca, M., İlhanb, F., Altana, H., Himc, A., Tütüncüa, M., Ozbekd H. (2005). Evaluation of hepatoprotective activity of Bergamot orange in rats. Eastern Journal of Medicine, 10(1-2), 1- 4.

Kim, H. K., Jeong, T. S., Lee, M. K., Park, Y. B., Choi, M. S. (2003). Lipid-lowering efficacy of hesperetin metabolites in highcholesterol fed rats. International Journal of Clinical Chemistry and Diagnostic Laboratory Medicine, 327(1-2), 129-37.

Krauss, R. M., Eckel, R. H., Howard, B. (2001). A statement for healthcare professionals from the Nutrition Committee of the American Heart Association. Journal of Nutrition, 131, 132-146.

Lee, H., Woo, M., Kim, M., Sook Noh, J., Song, Y. O. (2018). Antioxidative and cholesterol-lowering effects of lemon essential oil in hypercholesterolemiainduced rabbits. Preventive Nutrition and Food Science, 23(1), 8-14.

Mamidipally, P. K., Liu, S. X. (2004). First approach on rice bran oil extraction using limonene. European Journal of Lipid Science and Technology, 106(2), 122-125.

Mazza, G. (1987). Gas Chromatography and Mass Spectrometry study of the aromatic of mandarin essential oil. Sciences des Aliments, 7, 459-461.

Miceli, N., Mondello, M. R., Monforte, M.T., Sdrafkakis, V., Dugo, P., Crupi, M. L., Taviano, M. F., de Pasquale R., Trovato A. (2007). Hypolipidemic effects of Citrus bergamia Risso and Poiteau juice in rats fed a hypercholesterolemic diet. Journal of Agricultural Food Chemistry, 55, 1067110677.

Milagro, F. I., Campion, J., Martinez, J. A. (2006). Weight gain induced by high-fat feeding involves increased liver oxidative stress. Obesity, 14, 1118-1123.

More, T. A., Kulkarni, B. R., Nalawade M. L., Arvindekar, A. U. (2014). Antidiabetic activity of linalool and limonene in streptozotocin- induced rat: At combinatorial therapy approach. International Journal of Pharmacy and Pharmaceutical Sciences, 6(8), 159-163.

Njoroge, S. M., Koaze, H., Mwaniki, M., Minh Tu, N.T., Sawamura, M. (2005). Essential oils of Kenyan citrus fruits: Volatile components of two varieties of mandarins (Citrus reticulata) and a tangelo ( $C$. paradisi and $C$. tangerina). Flavour and Fragrance Journal, 20(1), 74-79.

Olshansky, S. J., Passaro, D. J., Hershow R. C., Layden, J., Carnes, B. A., Brody, J., Hayflick, L., Butler, R. N., Allison, D. B., Ludwig, D. S. (2005). A potential decline in life expectancy in the United States in 
the $21^{\text {st }}$ Century. New England Journal of Medicine, 352, 1138-1145.

Osfor, M. M. H., Hegazy, A., Abd El-Moaty, M. , Elmadbouly, M. A., Afify, A. M. R., Elbahnasawy, A. S. M. (2013). Hypocholesterolemic and hypoglycemic effects of orange albedo powder (Citrus aurantium L.) on male albino rats. International Journal of Nutrition and Food Science, 2(2), 70-76.

Ozbek, H., Bayram, İ., Cengiz, N., Uğraş, S. (2005). Evaluation of Foeniculum vulgare compounds of lethal dose levels and hepatoprotective effects. Turkish Pharmacological Society $18^{\text {th }}$ National Pharmacology Congress, September, IzmirTurkey, S40.

Pauli, A., Schilche, H. (2009). In Vitro Antimicrobial activities of essential oils monographed in the European pharmacopoeia. In: Hüsnü K., Baser C., Buchbauer G., editors. Handbook of essential oils; Science, Technology, and Applications. (pp. 353-547). CRC Press. Chapter 12.

Rao, V. N. M., Blane, K. (1985). PC-STAT, statistical programs for microcomputers. Version 1A. Department of Food Science and Technology. The University of Georgia, Athens, USA.

Ruangchai, Y., Lien, T. F. (2012). Effects of dietary limonene supplementation on growth performance, serum traits and antioxidant activities of rats. African Journal of Food Science and Technology, 3(1), 8- 15.

Russo, R., Ciociaro, A., Berliocchi, L., Cassiano, M.G.V., Rombolà, L., Ragusa, S., Bagetta, G., Blandini, F., Corasaniti, M.T. (2013). Implication of limonene and linalyl acetate in cytotoxicity induced by bergamot essential oil in human neuroblastoma cells. Fitoterapia, 89, 4857.

Santiago, J. V. A., Jayachitra, J., Shenbagam, M., Nalini, N. (2010). D-limonene attenuates blood pressure and improves the lipid and antioxidant status in high fat diet and L-NAME treated rats. Journal of Pharmaceutical Science and Research, 2(11), 752-658.

Schermer, S. (1967). The blood morphology of laboratory animals. (P. 350). Legman's Green and Co. Ltd.

Sharifi-Rad, J., Sureda, A., Tenore, G. C., Daglia, M., Sharifi-Rad, M., Valussi, M., Tundis, R., Loizzo, M. R., Ademiluyi, A. O., Iriti, M. (2017). Biological activities of essential oils: From plant chemoecology to traditional healing systems. Molecules, 22 (1), 70 - 125.

Sherwin, J. E. (1984). Liver function. In: Kaplan L. A. and PESCE A. J. ed. Clinical Chemistry, theory, analysis and correlation. (pp. 420-438). St Louis: Mosby.

Stuart, B., Schulz, H., Lager, E. (2001a). Classification and analysis of citrus oils by NIR spectroscopy. Food Chemistry, 72 (1), 113-117.

Stuart G. R., Lopes D., Oliveira J. V. (2001b). Deterpenation of Brazilian orange peel oil by vacuum distillation. Journal of the American Oil Chemists' Society, 78(10), 1041-1044.

Tebib, K., Rouanet, J. M., Beasancon, P. (1997). Antioxidants effects of dietary polymeric grape seed tannins in tissues of rats fed a high cholesterol vitamin $\mathrm{E}$ deficient diet. Food Chemistry, 59, 135141.

Terpstra, A. H., Iapra, J. A., de Varies, H. T., Beynen, A. C. (2002). The hypocholesterolaemic effect of lemon peel, lemon pectin and waste stream material of lemon peels in hybrid F1B hamsters. European Journal of Nutrition, 41, 19-26.

Tietz, N. W. (1976). Fundamentals of clinical chemistry. W. B. Saunders Co., Philadelphia, P. A.

Tietz, N.W. (1995). Clinical guide to laboratory tests. (pp 268-273). $3^{\text {rd }}$ ed. Saunders, Philadelphia.

Tzamtzis, N. E., Liodakis, S. E., Parissakis, G. K. (1990). The deterpenation of orange and 
lemon oils using preparative adsorption chromatography. Flavour and Fragrance Journal, 5(1), 56-67.

Vasudeva, N., Sharma T. (2012). Chemical composition and antimicrobial activity of essential oil of Citrus limettiodes Tanaka. Journal of Pharmaceutical Technology and Drug Research. ISSN 2050-120 X 1: 2. http://www.hoajonline.com/journals/pdf/20 50-120X-1-2.pdf

Virot, M., Tomao,V., Ginies, C., Visinoni, F., Chemat, F. (2008). "Green procedure with a green solvent for fats and oils' determination. Microwave-integrated Soxhlet using limonene followed by microwave Clevenger distillation. Journal of Chromatography A, 1196-1197 (1-2), 147-152.

Vora, D. J., Matthews, F R., Crandall, G. P., Cook, R. (1983). Preparation and chemical composition of orange oil concentrates. Journal of Food Science, 48 (4), 11971199.

Young, D. S. (1997). Effects of drugs on clinical laboratory tests. Annals of Clinical Biochemistry: International Journal of Laboratory Medicine, 34 (6), 579- 581.

Young, D. S., Thomas, D. W., Friedman, R. B., Pestaner, L. C. (1972). Effects of drugs on clinical laboratory tests. Clinical Chemistry, 18(10), 1041-1303

Zollner, N., Kirsch, K. (1962). Absorptimetric determination of total lipids in serum. Clinical Chemistry, 15, 544-549. 